\title{
Presidents of the United States and their Time After Office: An Analysis on a Misleading Notion of Presidents' Post-Presidential Activities
}

\author{
Pariwat Quangkananurug \\ Ruamrudee International School \\ Thailand
}

\begin{abstract}
There is often a false notion that explains that most presidents are inactive after their presidency. However, this is not true, and an underlying cause could be the fact that the more memorable presidents usually have short postpresidential time spans or die in office. With the world transition. Some of the more notable presidents that are active after office include the likes of Jimmy Carter, Herbert Hoover, and John Adams among others; and with the rise of social media and the internet, a spotlight will be shone upon the activities of ex-presidents.
\end{abstract}

Keywords: Presidents, United States, Post-presidency, Activities, Jimmy Carter

\section{Introduction}

When the subject of US presidents is brought up, the bulk of the discussion lies around events that happened under their presidency (Nixon and Watergate, Hoover and the Great Depressions, Lincoln and the Civil War) and their overall presidency. What is usually left out are their pre-presidential activities and post-presidential impacts. While it is common knowledge that most presidents are engaged in some form of work (politics, military, business), most people often neglect a president's post-presidency, assuming that they seclude themselves from the public and remain inactive for the majority of the time. This notion, however, is false. Most presidents, even some of the ones that had a short retirement, were active in one way or another.

\section{Examples of Post-Presidential Activities}

Figure 1. Presidents and their Post-Presidential Time Spans

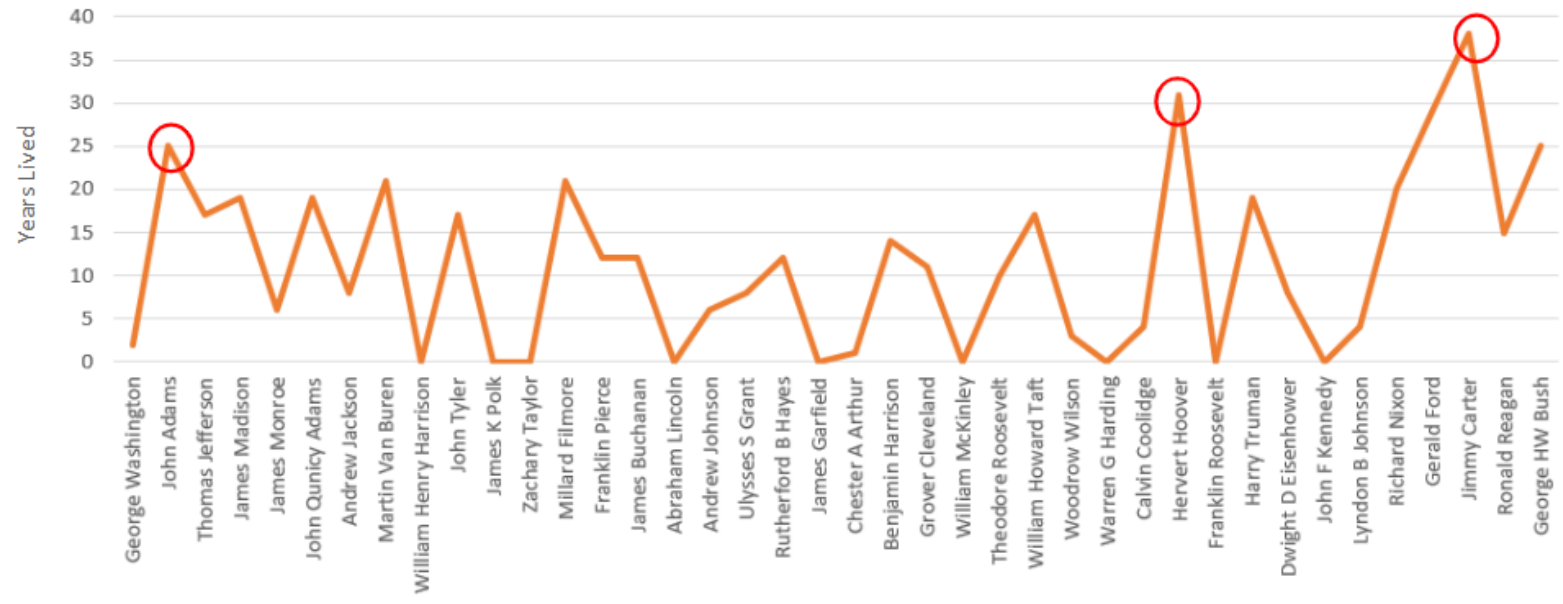

\subsection{Carter, Hoover, and John Adams}

From Graph 1, there are 3 notable peaks, denoting the 3 longest post-presidential timespans. These peaks represent John Adams, Herbert Hoover and Jimmy Carter (left to right). All three presidents were active after their presidencies, but in ways slightly different from one another. Jimmy Carter, probably the most well-known former president on the list, was very active outside of national politics. Carter was more involved in humanitarian initiatives, like the founding of the Carter Center, and diplomacy, such as his visit to North Korea in 2010 to negotiate the release of Ajailon Gomes [1] . This contrasted Herbert Hoover, who was mostly focused on national politics, more specifically, trying to take down Franklin Roosevelt, his successor. John Adams, though he also hated his successor, Thomas Jefferson, did not criticize him, and only jumped back into the political scene after Jefferson left office and during his son John Quincy Adams' presidential campaign. 
Jimmy Carter, considered by most as a mediocre president (ranked 26th overall in Siena's 6th Presidential Expert Poll in 2018) [2] , is arguably the greatest ex-president in the history of the United States. What separates Carter from most presidents is the fact that he was not seeking reelection after losing the first reelection. After losing in a landslide to Ronald Reagan, Carter founded the Carter Center just 3 months after leaving office. The Carter Center is described as a nonprofit organization that aims to "seek and resolve conflicts, enhance freedom and democracy, and improve health. [3]" The Center along with Carter himself has travelled across the globe for numerous health and peace programs, such as endorsing elections in Liberia, Jamaica, Mexico [4] and Yunnan [5], and the Guinea Worm eradication program in Africa [6].

In addition to the programs maintained by the Carter Center, Jimmy Carter has also travelled around the world for diplomatic missions as well as meeting up with World Leaders. Carter has helped negotiate many matters on the United States behalf, such as heading to Panama to help oust current dictator Manuel Noriega in 1989 [4] and monitor a 1990 Nicaraguan election, where he convinced ex-president Daniel Ortega Saavedra to step down after losing the election [4]. Carter also travelled to Nicaragua 4 years prior, ending his tour with the release of two political prisoners in Nicaragua [7]. Other notable missions include his meetup with Fidel Castro in 2002 to help strengthen US-Cuba relations [8] and Bashar Al-Assad in 2008 (most recently) to negotiate the release of prisoners [9].

Though it would seem that Carter's post-presidential activity was unusual, most presidents are quite active after office. Carter's activities were just larger and more frequent than the usual ex-presidents, making him seem like an anomaly. With arguably a subpar presidency, Jimmy Carter's post-presidential activities have become his legacy and main embodiment.

Herbert Hoover, unlike Jimmy Carter, was not particularly involved in foreign matters and humanitarian efforts. One of the few times Hoover did get involved in foreign matters was post World War 2, where Harry Truman sent Hoover to Germany to maintain the food needs of the nation [10]. Hoover was more involved in national politics and trying for reelections. Hoover was blamed for the Great Depression and was very unpopular during his reelection; as a result, he was defeated in a landslide in the 1932 presidential election by Franklin D Roosevelt [11]. The loss did not sit well with Hoover, and made him despise Roosevelt and his every action. Hoover was especially critical of Roosevelt's New Deal, calling it fascistic and stating "when the American people realize some ten years hence it was on November 8, 1932, that they surrendered the freedom of mind and spirit for which their ancestors had fought and agonized for over 300 years, they will, I hope, recollect that I at least tried to save them," [12] when regarding the New Deal. Hoover even used the New Deal as his main speech point during the 1936 Republic National Convention, where he attacked the policy and challenged its ideas [13], but Hoover lost to Alf Landon, who then was defeated by Franklin Roosevelt. Hoover also tried for reelection in 1940, but lost to Wendell Willkie who also lost to Franklin Roosevelt in the general election.

Hoover went to great lengths to try and destroy Roosevelt's presidency; he even declared that Hitler did not pose a threat to the United States, rather, it was Roosevelt that threatened the American peace [14]. Hoover also said that Roosevelt's policies deterred England and France while provoking Japan, and the US-USSR alliance would mean that the United States would be helping Stalin spread communism throughout Europe [35].

This is not to say that Hoover was the only ex-president to criticize his successors. JImmy Carter was also a massive critic of all his successors. Most recently, Carter called Donald Trump an "illegitimate president," claiming that Trump only won through Russian interference [15], to which Trump lashed back stating that "He (Carter) was a nice man. He was a terrible president." [16] Carter also disagrees with Trump's immigration policy, saying "Every day we send a disgraceful signal around the world, that this is what the president of the United States the United States government stands for, and that is torture and kidnapping of little children, separation from their parents and deprivation of those who are incarcerated." [17]

Interestingly enough, John Adams, did not criticize Thomas Jefferson at all. All three presidents mentioned (Adams, Hoover, Carter) seem to have problems with their successors, but Adams was the only one to refrain from saying anything negative, instead saying that "instead of opposing Systematically any Administration, running down their Characters and opposing all their Measures right or wrong, We ought to Support every Administration as far as we can in Justice." [18]This implies that Adams, though he may disagree with Jefferson's ideology or dislike him, would continue to support Jefferson as long as Jefferson can successfully maintain the United States. Jimmy Carter also said something similar regarding Reagan, stating that "it's too early to criticize Reagan," [19] only to start criticizing Reagan around a year into his presidency [20]

Adams' initial years of retirement actually followed the model of early presidents' retirement activities, which were to go back to their plantation and do farm work. However, like many early presidents, he also lost a lot of money in the farming business. 
After Jefferson retired, Adams started to become more public, by first publishing letters that attacked Hamilton. However, Adams decided to pull back his letters, in fear that his letters would make his son, John Quincy Adams, unsuccessful in his political career. It was only after his son joined the democratic-republicanparty that Adams again started to become more vocal.

\subsection{Other Examples}

Other examples of presidents that were active during their post presidencies include John Quincy Adams, William Howard Taft, Andrew Johnson, and Theodore Roosevelt, among others. Adams' post-presidency was similar to Johnson's and Taft's, where they held positions in public offices, with Adams' becoming a member of the House of Representatives [25], Johnson becoming a senator of Tennessee [24], and Taft becoming Chief Justice [26]. Roosevelt, like Hoover, also tried for a third term, though he stated that he would not. After returning from a world tour, Roosevelt tried to work with current president William Taft, whom he was good friends with, but resulted in their relationship turning sour [28]. After receiving endorsements for some republicans, Roosevelt decided to run for a third term, to which he created the Bull Moose Party, formally known as the Progressive Party. Roosevelt ultimately ended up losing to Woodrow Wilson.

An interesting example of a former president being active is John Tyler. Tyler lived 17 years after his presidency, and only became active one year before his death. Tyler initially worked as part of the Virginia Peace Conference in 1861 to draft a resolution. However, Tyler believed that the resolution proposed were skewed towards Northern benefits, and mainly opposed the resolution. When the Civil War broke out, Tyler was elected to the Confederate Congress and Confederate House of Representatives, to which he served until his death a few months later [27]. John Tyler remains the only president whose death is not formally recognized in Washington.

\subsection{Exceptions}

It should also be mentioned that not all presidents were active during their post-presidencies; presidents such as James Buchanan, Franklin Pierce, and Calvin Coolidge, were not extremely active after leaving office. With that being said, there seems to be an underlying reason why these presidents did not engage in any activities. James Buchanan, often blamed for causing the Civil War and regarded as one of the worst presidents ever (ranked 43 out of 44 in Siena's latest Presidential Expert Poll), was extremely unpopular after his presidency. During the Civil War, Buchanan stated that he supported the North, and repeatedly defended and justified his decisions during his presidency. This caused Buchanan to continuously receive death threats from the public, to the point where he wrote a defense, which was then published. Even his memoir, Mr. Buchanan's Administration on the Eve of the Rebellion, was also Buchanan defending himself. Franklin Pierce also falls into the same category as Buchanan, where he was receiving a lot of hate from the public. Though he kept up with politics during his world tour, he found himself defending himself from people calling him a traitor and a confederate spy due to false rumors and him being friends with Jefferson Davis before the war. As for Calvin Coolidge, his reason for not being politically active could be the fact that he only lived for 2 years after leaving office. Additionally, Coolidge also had no intention of returning to politics, adamantly refusing offers and instead going fishing and writing a column.

Another example of a president not being too active during their post-presidency is Ronald Reagan. During the initial years of his retirement, Reagan would give speeches and supporting the republican party candidates. However, after Reagan was diagnosed with Alzheimers, he started to become less active in the political scene [29]. As with Buchanan, Pierce, and Coolidge, there was an underlying reason to why Reagan was not so active in his 15 years after his presidency. Without these reasons, Reagan and the other presidents would likely have been involved in politics and engaged in various activities, as evident with Reagan being active before he was diagnosed with Alzheimers.

Other notable exceptions that should be noted are Thomas Jefferson and Harry Truman. Both Jefferson and Truman had relatively long post-presidencies (17 and 19 years respectively), but were not engaged in any political matters. After his presidency, Thomas Jefferson retired to Monticello and did what most early presidents did: work on his plantation as well as writing letters to his close correspondents [30]. A letter that Jefferson had written to James Monroe in October 1823 showed that Monroe asked for Jefferson's opinion on the doctrine [31]. However, other than letters and a reconciliation with John Adams, Jefferson was not involved in any political matters. Instead, Jefferson expanded his love for knowledge, founding the University of Virginia selling his books to the Library of Congress, and writing an autobiography. Harry Truman was also minimally in politics, where he would endorse the democratic candidates during their election, but that was mostly it. Truman refused any endorsements or corporate payroll, opting to live off of his army pension, living him in slight financial trouble. He did make some money from writing two memoirs, as well as additional pension from the Former Presidents Act, which was passed in 1958. 


\section{Misconceptions surrounding post-presidential activities}

The false notion that most presidents stay inactive after their presidency could stem from the fact that a good portion of the "greatest" presidents in the history of the United States had either short, uneventful post-presidencies or died in office. From Siena's 6th Presidential Expert Poll (2018) [2], the 10 greatest presidents of the United States are George Washington, Franklin D Roosevelt, Abraham Lincoln, Theodore Roosevelt, Thomas Jefferson, Dwight D Eisenhower, James Madison, James Monroe, Harry Truman, and John F Kennedy. From these 10 presidents, 3 presidents (Lincoln, F Roosevelt, Kennedy) died in office, 3 presidents (Washington, Eisenhower, Monroe) lived less than 10 years (mean post-presidential timespan) after leaving office, and 2 presidents (Jefferson and Truman) were not extremely active during their post-presidencies, as mentioned above. This means that 8 out of the 10 presidents did not have active postpresidencies, which could lead to someone falsely concluding that most presidents were inactive after their presidency.

Utilizing 2014 study by Henry Roediger and Andrew DeSoto examining the memorability of presidents [32], the data there also suggests that the more memorable presidents were not that active after their presidencies. Excluding the 4 most recent presidents (Barack Obama, George W and HW Bush, and Bill Clinton) and current president Donald Trump, the 10 most memorable presidents are George Washington, Abraham Lincoln, John F Kennedy, Richard Nixon, Jimmy Carter, Thomas Jefferson, Ronald Reagan, Gerald Ford, Franklin D Roosevelt and Theodore Roosevelt. Of the 10 presidents, 6 presidents (Washington, Lincoln, JFK, Jefferson, Reagan, and FDR) fall into the category of having an "inactive" presidency, supporting the claim that people could be falsely concluding that most presidents remain inactive after their presidency. Furthermore, when looking at the remaining 4 presidents (Richard Nixon, Jimmy Carter, Gerald Ford and Theodore Roosevelt), 3 out of the 4 presidents are fairly recent presidents, Nixon, Carter and Ford, meaning that the reason that these presidents are memorable is due to recency bias. When including the 4 most recent presidents back into the list, this becomes clearer, as top 4 most remembered presidents are the 4 most recent presidents.

As such, with a good portion of the "greatest" and most memorable presidents not being active during their postpresidencies, a false conclusion can easily be drawn stating that most presidents remain inactive after leaving office.

\section{Trends}

Over the centuries, the life expectancy of an average person has increased dramatically. In the 1800s, the average lifespan for an average white male would be around 37 years [33], where today it would be around 78 - 80 years old [34], almost double the age of someone living in the 19th century. This trend is also shown in the lifespans of U.S. presidents, where presidents nowadays are living up to 90 years old, where most presidents during the 19th century lived to around 70 years old (John Adams lived to 90 years, but that is an exception). This would mean that if presidents were to live longer, they would have a longer post-presidential timespan, which could lead them to become active in political matters and other activities.

This however, did not mean that earlier presidents were not active. This just means that as we move further into the future, we would most likely see presidents become increasingly active, and the false idea of presidents being inactive after their presidencies would be gone. In fact, this trend is already happening. Barack Obama, who left office in 2017, has already begun working on a Netflix documentary [21]. Other recent presidents like George W Bush and Bill Clinton have been known to make public appearances and being active overall. Bush has written many books, made appearances in various shows like the Tonight Show [22], and has taken up painting as a hobby. As for Bill Clinton, he has taken a route similar to Jimmy Carter's, though less rigorous, by founding the Clinton Foundation, which develops programs that "create economic opportunity, improve public health, and inspire civic engagement and service." [23] Clinton has also been campaigning for his wife Hillary during the 2016 presidential election.

\section{The Media and the Internet}

With our society becoming so technological, it is no surprise that there is more media coverage of presidents during and after their presidency. As mentioned before, the fact that people are living longer would immediately imply that most presidents in the modern era and in the future will have longer post-presidential timespans. Coupled with extensive media coverage, it should come as no surprise that public opinion on a presidents' post-presidency will change. Instead of viewing presidents as working only during their term, it will be soon recognized that most presidents, especially the future ones, are very active after their presidency.

Without the media, post-presidential activities like Jimmy Carter's or Bill Clinton's foundations will not be as widespread and well-known. Without the internet and television, people would not have known of George Bush's public appearances [22], Obama's ventures into the film industry [21], or even updates on what former presidents are doing. The fact of the matter is that with everything being documented and written down, it is inevitable that anything that a president does will be covered and broadcasted across the world. 
Donald Trump, the current President of the United States as of now, is already extremely active on the internet and being covered by the media, even before he has left office. His excessive, often controversial tweets and various interviews and media coverage has been featured in every corner of the internet. It would be no surprise that after his presidency, where he has a lot more leisure time, be extremely vocal and active on the internet and twitter. Though Trump's constant tweets may seem strange at first, this would most likely become the norm in the future. We are already seeing a good portion of politicians and governors possessing a twitter account or some sort of social media account, and there is no doubt that more and more politics-related people will have a social media handle.

As such, the fact people overall are living longer combined with the increasing frequency of internet usage and media coverage, future presidents are most likely going to be extremely active after their terms end.

\section{References}

McCurry, Justin (2010) - North Korea Releases Us Prisoner After Talks with Jimmy Carter . Retrieved from: https://www.theguardian.com/world/2010/aug/27/north-korea-us-prisoner-jimmy-carter

Siena College Research Institute. (2019). Siena's 6th Presidential Expert Poll 1982 - 2018. Retrieved from: https://scri.siena.edu/2019/02/13/sienas-6th-presidential-expert-poll-1982-2018/. The Carter Center. (n.d.). Our Mission. Retrieved from : https://www.cartercenter.org/about/index.html.

Chambers, J. (1998). Jimmy Carter's Public Policy Ex-Presidency. Political Science Quarterly,113(3), 405-425. Retrieved from: https://www.jstor.org/stable/2658074 doi:10.2307/2658074

The Carter Center. (2010). March 2010 Villagers Committee Elections in Yunnan Province, China. Retrieved from: https://www.cartercenter.org/resources/pdfs/peace/china/2010-china-village-elections-rpt.pdf.

The Carter Center. (Updated 2019). Guinea Worm Eradication Program. Retrieved from: https://www.cartercenter.org/health/guinea_worm/.

Wilkinson, T. (1986). Former President Jimmy Carter, ending a three-day tour of Nicaragua. Retrieved from: https://www.upi.com/Archives/1986/02/09/Former-President-Jimmy-Carter-ending-a-three-day-tourof/7251508309200/.

Carter, J. (2002). President Carter's Cuba Trip Report. Retrieved from: https://www.cartercenter.org/news/documents/doc528.html.

Worth, R. F. (2008). Defying Israel, Carter Meets Hamas Leader. Retrieved from: https://www.nytimes.com/2008/04/19/world/middleeast/19carter.html.

Hamilton, D. E. (n.d.). Herbert Hoover: A Life After Presidency. Retrieved from: https://millercenter.org/president/hoover/life-after-the-presidency.

Leip, D. (n.d.). 1932 Presidential General Election Results. Retrieved from: https://uselectionatlas.org/RESULTS/national.php?year=1932\&f $=0$ \&off $=0 \&$ elect $=0$.

Short, B. (1991). The Rhetoric of the Post-Presidency: Herbert Hoover's Campaign against the New Deal, 1934-1936. Presidential Studies Quarterly,21(2), 333-350. Retrieved from: http://www.jstor.org/stable/27550722

Hoover, H. (1936). Crisis to Free Men. Retrieved from: https://publicpolicy.pepperdine.edu/academics/research/faculty-research/new-deal/hooverspeeches/hh061036.htm.

LUKACS, J. (1993). HISTORY: Herbert Hoover Meets Adolf Hitler. The American Scholar,62(2), 235-238. Retrieved from: http://www.jstor.org/stable/41212096

Holpuch, A. (2019). Jimmy Carter: 'illegitimate' Trump only president because of Russian meddling. Retrieved from: https://www.theguardian.com/us-news/2019/jun/28/jimmy-carter-trump-illegitimate-president-russia.

Moran, L. (2019). Donald Trump Fires Back At Jimmy Carter Over Illegitimate President Suggestion. Retrieved from: https://www.huffpost.com/entry/donald-trump-jimmy-carter-hits-back_n_5d172d65e4b07f6ca57dae67.

Isaac. (2019). Jimmy Carter says the Trump administration is torturing and kidnapping little children (Video). Retrieved from: https://redreporttoday.com/index.php/2019/jimmy-carter-says-the-trump-administration-istorturing-and-kidnapping-little-children-video/.

Adams, J. (1808). From John Adams to Benjamin Rush, 18 April 1808. Retrieved from: https://founders.archives.gov/documents/Adams/99-02-02-5238.

Thomas, H. (1981). Too early to criticize Reagan, says Carter. Retrieved from: https://www.upi.com/Archives/1981/03/16/Too-early-to-criticize-Reagan-says-Carter/2336353566800/.

Clymer, A. (1982). Carter Says Reagan has Failed to Accept Responsibilities Retrieved from: https://www.nytimes.com/1982/10/01/us/carter-says-reagan-has-failed-to-accept-his-responsibilities.html. 
Associated Press. (2018). Barack and Michelle Obama sign deal with Netflix to produce films and series. Retrieved from: https://www.scmp.com/news/world/united-states-canada/article/2147170/barack-and-michelle-obamasign-deal-netflix-produce.

Naylor, B. (2017). Former President Bush Says SNL Impressions Never Bothered Him A Bit. Retrieved from: https://www.npr.org/2017/03/03/518329705/former-president-bush-says-snl-impressions-never-bothered-hima-bit.

Clinton Foundation. (n.d.). About Us. Retrieved from: https://www.clintonfoundation.org/about.

United States Senate. (n.d.). Andrew Johnson. Retrieved from: https://www.senate.gov/artandhistory/art/artifact/Sculpture_22_00016.htm.

United States House of Representative. (1825). The House of Representatives Elected John Quincy Adams as President. Retrieved from: https://history.house.gov/Historical-Highlights/1800-1850/The-House-ofRepresentatives-elected-John-Quincy-Adams-as-President/.

Encyclopaedia Britannica. (updated 2019). William Howard Taft. Retrieved from: https://www.britannica.com/biography/William-Howard-Taft.

Encyclopaedia Britannica. (updated 2019). John Tyler. Retrieved from: https://www.britannica.com/biography/JohnTyler.

Cengage. (updated 2019). Taft-Roosevelt Split. Retrieved from: https://www.encyclopedia.com/history/dictionariesthesauruses-pictures-and-press-releases/taft-roosevelt-split.

Rothman, L. (2016). Read Ronald Reagan's Letter to the American People About His Alzheimer's Diagnosis. Retrieved from: https://time.com/4473625/ronald-reagan-alzheimers-letter/.

Onuf, P. (n.d.). Thomas Jefferson: Life After the Presidency. Retrieved from https://millercenter.org/president/jefferson/life-after-the-presidency.

Jefferson, T. (1823). Thomas Jefferson on the Monroe Doctrine. Retrieved from https://www.mtholyoke.edu/acad/intrel/thomas.htm.

Roedinger, H. L., \& DeSoto, K. A. (2014). Forgetting the Presidents. Retrieved from: https://pdfs.semanticscholar.org/3b88/b8d4f8b4e323c3c3e6b79688a93bb057bd43.pdf.

Riley, J. (2005). Estimates of Regional and Global Life Expectancy, 1800-2001. Population and Development Review,31(3), 537-543. Retrieved from: http://www.jstor.org/stable/3401478

Arias, E. (2002). United States Life Tables, 2000. Retrieved from https://www.cdc.gov/nchs/data/nvsr/nvsr51/nvsr51_03.pdf.

Encyclopaedia Britannica. (updated 2019). Herbert Hoover. Retrieved from https://www.britannica.com/biography/Herbert-Hoover. 